School of Public Health, University of Haifa, Haifa, Israel

2 Texas A\&M Transportation Institute, College Station, Texas, USA

3 Monash Sustainable Development Institute and School of Social Sciences, Monash University, Melbourne, Australia

4 Damour for Community Development, Palestine

5 Department of Geography and Environmental Development, Ben-Gurion University of the Negev, Beersheba, Israel

Correspondence to: M Negev mnegev@univ.haifa.ac.il

Cite this as: BMJ 2020;371:m3000

http://dx.doi.org/10.1136/bmj.m3000

Published: 16 November 2020

HEALTHY DRY CITIES

\title{
City design for health and resilience in hot and dry climates
}

Cities in regions including the Middle East can use a variety of approaches to promote wellbeing among the people who live and work there despite dryness and heat, write Maya Negev and colleagues

Maya Negev, ${ }^{1}$ Haneen Khreis, ${ }^{2}$ Briony C Rogers, ${ }^{3}$ Mohammed Shaheen, ${ }^{4}$ Evyatar Erell ${ }^{5}$

The health of people living in cities is affected by urban design elements including density, distribution of land use, building design, transport infrastructure, green spaces, opportunities for social interaction, and accessibility to work, education, healthy food, and culture. ${ }^{12}$ Several of these elements pose particular challenges when designing healthy cities in hot and dry regions such as the Middle East, where weather may constrain active transport, outdoor recreational physical activity, and outdoor socializing.

Studies of the impact of urban design on health in arid regions is scarce, ${ }^{3}$ with most research from the global north. A climate and culturally sensitive approach can, however, inform adaptation of evidence from temperate climates to hot and dry climates (table). 


\section{Table | Design strategies to promote health in hot and dry cities}

\begin{tabular}{|c|c|c|}
\hline Strategy & Health benefits & Adaptation to hot and dry cities \\
\hline \multicolumn{3}{|l|}{ Urban form } \\
\hline Increased built density and land use diversity ${ }^{4}$ & $\begin{array}{l}\text { Encourages active transport (walking and cycling); improves } \\
\text { accessibility to work, social networks, and health services }\end{array}$ & $\begin{array}{l}\text { Short walking distances to reduce exposure to hot weather and } \\
\text { solar radiation }\end{array}$ \\
\hline Dense network of pedestrian and cycling paths ${ }^{5}$ & Encourages active transport; improves accessibility & Shade is essential for pedestrians and cyclists \\
\hline Compact urban design 6 & Encourages active transport & $\begin{array}{l}\text { Narrow streets and courtyards provide shade in the day but } \\
\text { increase nocturnal urban heat island intensity }\end{array}$ \\
\hline $\begin{array}{l}\text { Diverse range of water sources, including recycled water } \\
\text { and harvested storm water }\end{array}$ & Ensures water is available, even during dry periods & $\begin{array}{l}\text { Seasonal rainfall patterns need to be considered in developing } \\
\text { water resources strategy }\end{array}$ \\
\hline \multicolumn{3}{|l|}{ Urban design details } \\
\hline $\begin{array}{l}\text { Green space with tree canopies adjacent to main pedestrian } \\
\text { and cyclist areas }{ }^{8}\end{array}$ & $\begin{array}{l}\text { Improves thermal comfort } \\
\text { Exposure to fresh air } \\
\text { Psychological wellbeing }\end{array}$ & $\begin{array}{l}\text { Modest size to conserve water } \\
\text { Waterbodies are usually not possible owing to water shortage } \\
\text { Emphasis on shade trees }\end{array}$ \\
\hline Spatial design that considers wind and natural ventilation 9 & Encourages active transport & $\begin{array}{l}\text { Built form and shade elements should allow breezes to cool } \\
\text { pedestrians and cyclists } \\
\text { Moderately non-uniform building heights promote ventilation } \\
\text { without introducing wind hazards and mechanical discomfort }\end{array}$ \\
\hline $\begin{array}{l}\text { Use of suitable color materials in public spaces and on } \\
\text { walking and cycling paths }\end{array}$ & Prevents surface heating and reduces heat emission & $\begin{array}{l}\text { Colors should be relatively light to avoid surface heating, but } \\
\text { not very light to avoid thermal discomfort and glare from } \\
\text { reflected sunlight }\end{array}$ \\
\hline $\begin{array}{l}\text { Restriction of vehicle access and defined pedestrian and } \\
\text { cyclist only zones }{ }^{1}\end{array}$ & Encourages active transport & Provide shade and green spaces in such zones \\
\hline $\begin{array}{l}\text { Priority given to cyclists and pedestrians over motor } \\
\text { vehicles } 1\end{array}$ & Encourages active transport; reduces road travel injuries & $\begin{array}{l}\text { Convenient active transport reduces overexposure to heat and } \\
\text { solar radiation }\end{array}$ \\
\hline \multicolumn{3}{|l|}{ Transport planning and policy } \\
\hline $\begin{array}{l}\text { Increased accessibility and connectivity of public transport }{ }^{11} \\
\text { Reduced distances from residential and work zones to public } \\
\text { transport stops and connected walking and cycling paths }\end{array}$ & $\begin{array}{l}\text { Improves accessibility; potentially encourages active transport } \\
\text { as a component of public transport trips }\end{array}$ & $\begin{array}{l}\text { Short walking distances to reduce exposure to hot weather } \\
\text { Shaded or cooled public transport stops }\end{array}$ \\
\hline $\begin{array}{l}\text { Zoning codes specifying maximum vehicle parking instead } \\
\text { of minimum requirements } 12\end{array}$ & Discourages private vehicles & No special adaptation \\
\hline $\begin{array}{l}\text { Appropriate cycling and walking signs; pavement marking } \\
\text { and street lights } 13\end{array}$ & Encourages active transport; reduces road travel injuries & No special adaptation \\
\hline \multicolumn{3}{|l|}{ Building design } \\
\hline Walls and roofs protect from climatic extremes ${ }^{14-17}$ & $\begin{array}{l}\text { More resilience to disruptions in power supply and extreme } \\
\text { weather } \\
\text { Less morbidity and mortality, especially during heat waves } \\
\text { Less dependence on air conditioning } \\
\text { Mitigate for fuel poverty } \\
\text { Less greenhouse gas emissions }\end{array}$ & $\begin{array}{l}\text { Well insulated walls and roofs } \\
\text { High thermal mass stabilizes indoor temperature } \\
\text { High reflectance roofs } \\
\text { Green roofs may require irrigation so are suitable only where } \\
\text { water is plentiful } \\
\text { Passive cooling, especially night ventilation to flush daytime } \\
\text { heat }\end{array}$ \\
\hline $\begin{array}{l}\text { Windows promote natural ventilation, daylight, and passive } \\
\text { solar heating, but protect from unwanted heat }\end{array}$ & & $\begin{array}{l}\text { Moderate sized windows on north and south facing walls, small } \\
\text { ones on east and west facing ones. Large equator facing } \\
\text { windows if passive heating is required } \\
\text { Windows open to allow cross ventilation } \\
\text { Operable external shading } \\
\text { Cool glazing provides light but reduces solar heat gain }\end{array}$ \\
\hline
\end{tabular}

\section{Challenges: rising dryness and heat}

Urban design can mitigate for the lack of water and high temperatures, which present a dual challenge to designing urban environments that promote public health (fig 1). 


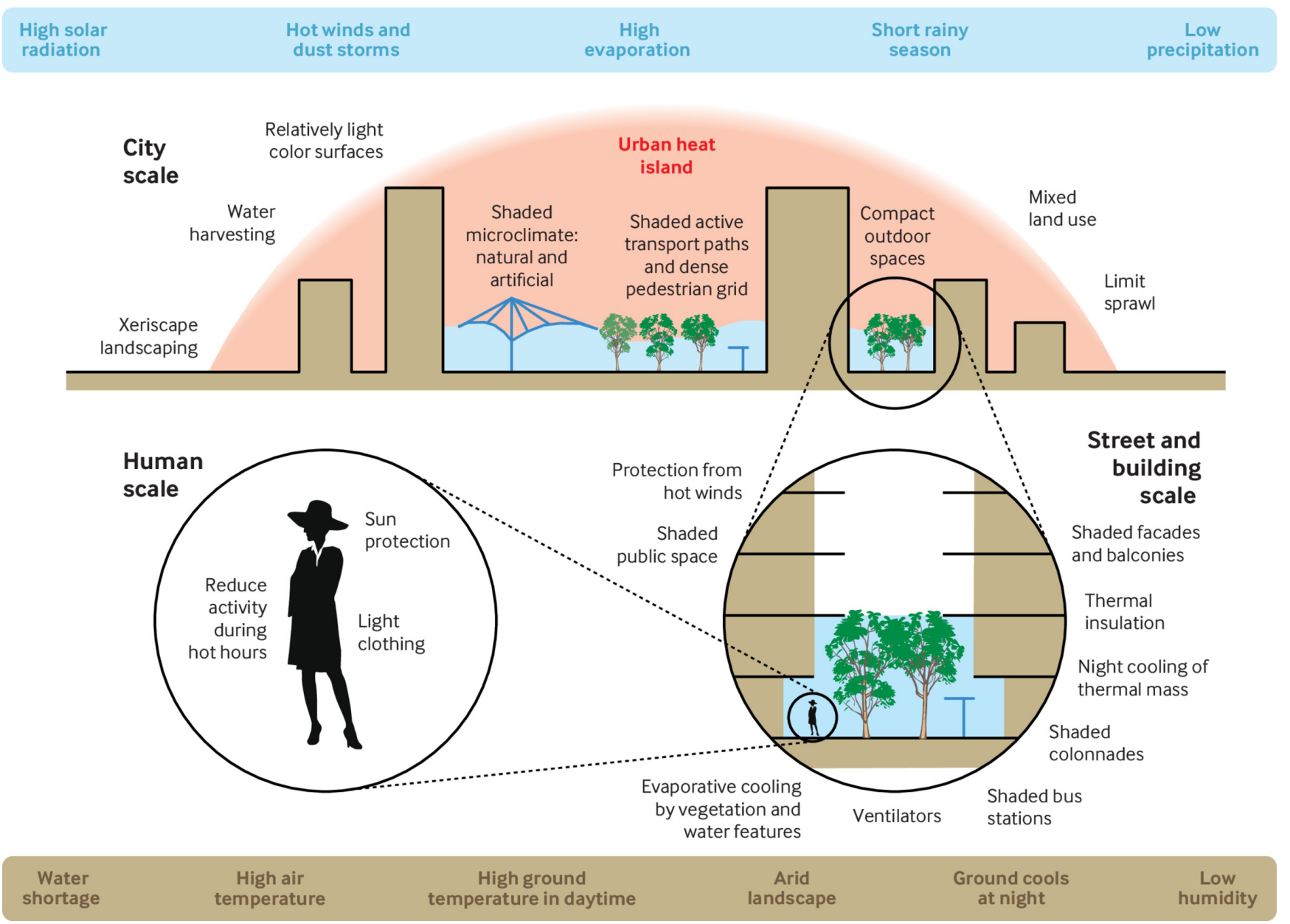

Fig 1 | Environmental conditions in hot and dry cities (blue and brown), and city, street, and building, and human scale means for designing a healthy city in hot and dry climate. Created by Eran Kaftan for the authors

Extreme water shortages, long dry summers, and high potential evaporation are barriers to green spaces, which are a common feature of heat mitigation strategies in healthy cities in temperate climates but are more difficult to establish and maintain in arid climates.

High temperatures and intense solar radiation can cause thermal discomfort and heat stress. High temperatures are also associated with increased morbidity and mortality ${ }^{20}$; even small reductions in heat stress can mitigate cardiovascular and respiratory morbidity. ${ }^{21}$

Cities in dry climates also have more intense night time urban heat islands than cities in temperate and tropical climates, though they often have modest daytime cool islands because they have more vegetation than the surrounding desert. ${ }^{22}$

These challenges are amplified by climate change, which has already resulted in rising temperatures and increased intensity, duration, and frequency of heatwaves as well as reduced precipitation in regions including the Middle East-trends that are expected to continue. ${ }^{23}$ Climate projections suggest that heat related mortality risk in this region will increase 2-3 fold in the near future. ${ }^{24} 25$

Cities can adapt to climate change through resilience strategies-for example, by designing urban spaces, transportation systems, and buildings that increase their capacity to adapt to heatwaves and recover from hazards such as droughts and floods, while maintaining essential functions (box and table). ${ }^{29}$

\section{Box 1: Urban resilience initiatives in the Middle East}

- The World Health Organization Eastern Mediterranean Regional Office (WHO EMRO) established in 1990 a regional healthy cities network initiative which 77 cities have joined, with a population of over 22 million from 13 countries including Saudi Arabia, Iran, and the United Arab Emirates. ${ }^{26}$ The network improves urban resilience in line with the SDGs. After joining the network, cities are required to implement $80 \%$ of 80 indicators in nine health and resilience domains, including emergency preparedness and response, health governance, water and sanitation, and social capacities. The city of Sharjah (United Arab Emirates) was the first to be awarded as a healthy city in the region, after meeting $88 \%$ of the indicators (http://sha.gov.ae/en/sharjah_health_city/).

- The 100 Resilient Cities initiative of the Rockefeller Foundation (2013-19) endorsed cities in the region including Ramallah, Amman, Beirut, Luxor, and Tel Aviv-Yafo to develop strategic resilience plans. The Amman strategic plan, for example, sets to improve the transportation system, promote walkability, apply green building guidelines, manage water resources efficiently, and institutionalize planning in the city. The Ramallah strategic plan includes urban design dimensions such as increasing green spaces and establishing a formal public transport system to improve mobility of women. ${ }^{27}$ Tel Aviv-Yafo adopted mandatory green building standards, pioneered bicycle and scooter rental schemes and developed an extensive network of dedicated paths for them, and is devising a climate change readiness plan that includes more shading and natural vegetation, cooling public facilities and public spaces, and mitigation of the urban heat island. ${ }^{28}$ Tel Aviv-Yafo and Amman are also 
members of the $\mathrm{C} 40$ network of world megacities committed to addressing climate change.

\section{Urban form for healthy hot and dry cities}

Modern urban planning has been car centric and has encouraged urban sprawl everywhere, but healthy desert cities should be compact, following tradition. ${ }^{2}$ Compactness is especially important in desert cities, because unlike temperate or tropical climates, open space that is left unirrigated grows no vegetation and is a source of dust. ${ }^{30}$ While strategies to create compact, dense cities are undergoing scrutiny because of the covid-19 pandemic, hyper-dense cities such as Hong Kong, Seoul, and Tokyo showed that avoiding large outbreaks is possible with timely public health measures. ${ }^{31}$

Urban form affects physical activity, ${ }^{32}$ and well designed compact cities such as Amsterdam and Portland, Oregon, promote outdoor physical activities and social interactions in ways that reduce people's exposure to infection risk indoors-for example, by expanding sidewalks and prioritizing cycling paths. Compactness and connectivity also increase access by foot or bike, reducing reliance on public transport. ${ }^{2}$

\section{"Nature based solutions" and "water sensitive cities"}

"Nature based solutions" incorporate natural or modified ecosystems into urban design and have been shown to benefit human wellbeing in temperate climates as well as biodiversity. 3334

Vegetation can provide cooling in several ways. Tree canopies create shade and reduce land surface temperature by intercepting solar radiation. Evapotranspiration releases water vapor into the atmosphere through a combination of evaporation from water surfaces and soil moisture and transpiration from plants, which lowers air temperature while increasing humidity. ${ }^{35}$ Living in areas which are cooler and with more vegetation is associated with reduced risk for heat related morbidity and mortality. ${ }^{36}$

Plants need a reliable source of water. This may be achieved through a "water sensitive city" approach, which integrates water cycle management with urban planning and design processes to maximize available water resources while generating additional community wellbeing and ecological benefits. ${ }^{37}$ This visionary concept emerged in Australia in response to challenges with traditional water planning based on historic rainfall patterns that are no longer reliable, and a recognition of the community's growing expectations for healthy, livable urban environments. ${ }^{38}$

Three key principles guide water sensitive practices. ${ }^{39}$ Firstly, they access a range of water sources efficiently to ensure availability for public consumption and irrigation of open spaces, even in periods of drought.

Secondly, they increase and protect ecosystems including waterways, wetlands, river basins, and coasts-for example, constructed wetlands and biofilters capture, retain, and treat stormwater in the urban landscape, providing local cooling, greening, and reduced run-off pollution..$^{\circ}$ Such amenities have multiple health benefits for mental and physical health by offering greater opportunities for physical activity, passive recreation, and social connection. ${ }^{41}$

Thirdly, water sensitive communities value their city's green spaces and waterways, adopt behaviors that conserve water and reduce pollution, and support the policy and governance arrangements needed to deliver health and wellbeing outcomes through better water management.
For example, Melbourne, Australia, aspires to be a water sensitive city-it recycles wastewater and captures stormwater to supply water for non-drinking uses; biofiltration rain gardens have been implemented across the city; and its community feels strongly connected to water issues and policy decisions. $4^{2}$

\section{Greening public space}

In the hot and dry climate of the Middle East many cities lack the water required for urban greening. Adopting nature based and water sensitive urban design solutions that were developed for a temperate climate may be unsuccessful because rain is concentrated in the winter, followed by six to seven months of no rain.

In dry cities, public green space must be designed judiciously to target benefits to places most likely to be enjoyed by as many city residents as possible, ${ }^{43}$ with consideration given to underprivileged neighborhoods, which are often neglected in this respect, and to social and cultural norms-for example, by providing zones for women. 44

Smaller areas of green space compared with temperate climate cities reduce irrigation requirements. Because plants adapted to the desert minimize water loss by evapotranspiration, they have only a minor effect on air temperature and improve thermal comfort primarily by providing shade (in the case of trees) or by reducing heat emitted from the ground surface in the form of infrared radiation. Both benefits are localized, so vegetation should be prioritized for main pedestrian and cycling paths, plazas, and courtyards. Xeriscape gardening - that is, landscaping that reduces or eliminates the need for irrigation-can substitute for water intensive green spaces. ${ }^{45}$

\section{Keeping cool in hot cities}

Thermal comfort is not just about air temperature; it is also affected by radiant exchange, humidity, and air movement, and may be assessed by complex indicators such as the universal thermal climate index (UTCI). ${ }^{46}$ Such indicators may be used to compare alternative designs for urban spaces to enhance resilience and to promote walkability and outdoor activity. 47

In contrast to temperate cities, where exposure to sunshine is considered beneficial for mental health and vitamin D synthesis, cities in hot and dry climates should provide shade. Trees deliver cooling more efficiently, in terms of water use, than grass or other non-shading plants. ${ }^{8}$ Artificial shading, such as fabric canopies, pergolas, or arcades, can provide solar protection in urban corridors and recreational spaces where vegetation cannot be planted. Shading reduces land surface temperature by intercepting solar radiation and significantly improves human thermal comfort. It is preferable to highly reflective pavement, which despite being cooler than dark surfaces increases the radiant load on pedestrians and has an overall negative effect on comfort..$^{8}$ It also reduces exposure to the ultraviolet light that causes sunburn and skin cancer. 49

\section{Promoting active and public transport}

Urban transport affects mobility and access to jobs, education, goods, services including healthcare, and social networks, all with links to public health. Encouraging shifts from car travel to public transport and active transport (walking and cycling) can improve health in cities by increasing physical activity and exposure to green spaces while reducing air pollution, noise, social exclusion, injuries, stress, and community severance-that is, physical or psychological barriers to mobility caused by busy roads. ${ }^{150}$ Health benefits from such a shift outweigh potential adverse effects of sustaining injuries while walking or cycling and exposure to air pollution, and reduce greenhouse gas emissions. ${ }^{1}$ 
However, hot and dry climates present unique challenges for designing healthy transport systems. Although the connections between transport planning and policy and public health are well researched, ${ }^{150}$ best practices for application in hot and dry cities have not been synthesized.

For example, active and public transport may be hard to implement in hot and dry cities..$^{52}$ Research shows that warm temperatures $\left(24^{\circ}-30^{\circ} \mathrm{C}\right)$ and dry and sunny weather encourage walking and cycling over car travel, but higher temperatures and humidity have the opposite effect owing to thermal and mechanical discomfort. ${ }^{5253}$ Similarly, use of public transport, which often demands walking or cycling part of the route, is reduced in extreme weather such as very high temperatures. ${ }^{11}$

Evidence originates mostly from areas of temperate climate in Europe, North America, and Australia, although inhabitants of hot and dry climates may become acclimatized to different combinations of temperature, humidity, and solar radiation.

Evidence indicates also that women and older people are more sensitive to thermal comfort than men and younger adults. This is particularly relevant in Middle Eastern countries including Qatar, Iran, and Saudi Arabia, where women's clothing tends to be heavier and their skin more covered because of religious, social, and cultural factors. This might deter active transport and increase the existing gender divide in physical activity. ${ }^{53}$ Restricted interactions between women and men are another barrier for women using public and active transport.

Public transport can be a healthy mode of transport, but it needs to be weather resilient: hubs should be sheltered and accessible, service should be reliable and frequent, and buses, trams, trains, and indoor stations should be thermally comfortable. ${ }^{54}$

Improving car efficiency and electrification are additional measures to promote health through reducing greenhouse gas emissions and air pollution..$^{51}$ Electricity should be decarbonized and generated from solar energy. .5

\section{Designing healthy buildings}

Modern societies spend about $90 \%$ of their time indoors, ${ }^{56}$ so the design of buildings has major implications for health and wellbeing. Improved indoor environmental quality has measurable benefits: increased ventilation and optimized daylight and views increase sleep duration ${ }^{57}$ and improve cognitive performance. ${ }^{58}$ Poor indoor environmental quality - primarily indoor pollutants, often characterized as "sick building syndrome"-is common in offices and schools owing to central air conditioning, adversely affecting attendance and performance. 59

All buildings create an indoor environment distinct from outdoor conditions. The walls and roof form an enclosure that may be sealed or permeable to various degrees, depending on weather conditions, allowing exchange of heat, light, and air. The exchange can be controlled by mechanical systems, as in many modern buildings; by passive means, as in traditional construction; or by a mixture of the two. All climatic solutions should also be sensitive to visual and acoustic privacy, which are affected by social and cultural norms that vary among societies.

Climate sensitive design of buildings seeks to maximize the advantages of local conditions and mitigate their drawbacks, while minimizing the use of non-renewable resources, especially energy, to improve sustainability. In hot climates, this means limiting unwanted solar heating and integrating passive cooling to release excess heat to the environment, in addition to providing well controlled daylight and plenty of fresh air.

In a well designed house, a combination of internal thermal mass and external thermal insulation can keep indoor air temperature within a narrow band of $2-3^{\circ} \mathrm{C}$ without air conditioning, even if the diurnal outdoor temperature range is $15-20^{\circ} \mathrm{C} \cdot{ }^{18}$ Excess heat absorbed in the building during the daytime can be released to the environment at night by opening strategically placed windows, to allow cross ventilation. ${ }^{14}$ However, as heatwaves become more frequent and prolonged as a result of climate change, indoor conditions may exceed critical thresholds in many climates that rely on indoor cooling. ${ }^{15}$ Many buildings constructed today will still be in service in 50 or even 100 years, so current building codes should be modified in response to modeled future climate.

The challenge for architects is to use innovative materials to reduce dependence on the ubiquitous air conditioners that now give occupants greater flexibility and improved thermal comfort compared with traditional vernacular passive cooling systems in buildings. ${ }^{60}$ Well designed modern buildings perform better in extreme weather, reducing morbidity and mortality, and improve resilience to disruptions in power supply. ${ }^{15}$ By reducing dependence on air conditioning, especially during heatwaves, buildings can also reduce greenhouse gas emissions and can mitigate for energy poverty, which affects nearly 1.3 billion people globally who have no access to electricity (mostly in hot climates) or for whom it is simply too expensive. ${ }^{61}$

\section{Governance in healthy dry cities}

Urban resilience is linked with most of the United Nations sustainable development goals (SDGs), particularly SDG 11: making cities inclusive, safe, resilient and sustainable, focusing on healthy living, and ensuring availability and sustainability of water and sanitation.

Increasing resilience in hot and dry cities will depend on governance that ensures timely, collaborative, integrative, and adaptive processes with a long term vision. Key barriers to adaptive and water sensitive urban governance include sectoral silos, fragmented policy and regulations, lack of vision and leadership, lack of incentives, limited practitioner capacity, inadequate funding and financing models, and lock-in to traditional practices. ${ }^{62}$ Moreover, water shortage often requires national infrastructure, and innovative water storage and recycling requires capacity and often costly technology. ${ }^{7}$

Individual cities in the Middle East have taken local measures to increase urban resilience-for example, Saudi Arabian cities started adopting sustainable buildings, public transport, and urban greening strategies. ${ }^{55}$ Examples include xeriscape gardening with natural elements in Riyadh, and green and blue spaces using recycled waste water south of Riyadh. ${ }^{45}$

Region-wide initiatives in the Middle East have also sought to improve urban resilience (box 1). Some of these include urban design measures to increase walkability and encourage green buildings. But mostly they are based on strategies from temperate urban areas adapted to the local climate and to climate change. To translate these plans into actions, cities might increase urban design and planning, coordinate between central and local levels of government, increase participation of all stakeholders, and allocate adequate resources. 


\section{Key recommendations}

- Climate sensitive urban design: create compact cities with shaded public spaces, using trees and artificial shading

- Connectivity and accessibility: emphasize public transport with passive cooling in stations and cooling in buses, trams, and trains; shaded and safe pedestrian and bicycle lanes, providing access to work, leisure, and services; efficiency and electrification of vehicles, charged by solar energy

- Climate sensitive buildings: design for indoor thermal comfort, fresh air, and well controlled daylight and solar heating

- Redefine open space: use innovative arid landscape architecture for water efficient and health promoting parks and public spaces

- Culture sensitive urban design: strategies should be sensitive to social and cultural norms

- Resilience and adaptation to climate change: design cities, buildings, and transportation that maintain their functions in a changing climate

Competing interests: We have read and understood BMJ's policy on competing interests and declare the following: none.

Provenance and peer review: Commissioned; externally peer reviewed.

This article is part of a series commissioned by The BMI for the World Innovation Summit for Health (WISH) 2020. The BMJpeer reviewed, edited, and made the decisions to publish. The series, including open access fees, is funded by WISH.

We thank Howard Frumkin for his comments. Drs Negev, Shaheen, and Khreis thank the Arava Institute and the Track II Environmental Forum for facilitating dialogues in the region which enabled their collaboration.

1 Nieuwenhuijsen M, Khreis H. Integrating human health into urban and transport planning: a framework. Springer International Publishing, 2018

2 Dannenberg AL, Frumkin H, Jackson R. Making healthy places: designing and building for health, well-being, and sustainability. Island Press, 2011.doi: 10.5822/978-1-61091-036-1

3 Al-Delaimy WK. Vulnerable populations and regions: Middle East as a case study. In: Health of people, health of planet and our responsibility. Springer International Publishing, 2020: 121-33. doi: 10.1007/978-3-030-31125-4_10

4 Mouada N, Zemmouri N, Meziani R. Urban morphology, outdoor thermal comfort and walkability in hot, dry cities. International review for spatial planning and sustainable development A: Planning Strategies and Design Concepts. Int Rev Spatial Plan Sust Dev 2019;7:117-33. doi: 10.14246/irspsda.7.1_117

5 Johansson E. Influence of urban geometry on outdoor thermal comfort in a hot dry climate: A study in Fez, Morocco. Build Environ 2006;41:1326-38doi: 10.1016/j.buildenv.2005.05.022

6 Erell E. The application of urban climate research in the design of cities. Adv Build Energy Res 2008;2:95-121doi: 10.3763/aber.2008.0204

7 Grant SB, Fletcher TD, Feldman D, etal. Adapting urban water systems to a changing climate: lessons from the millennium drought in southeast Australia. Environ Sci Technol2013;47:10727-34. doi: 10.1021/es400618z pmid: 23641731

8 Shashua-Bar L, Pearlmutter D, Erell E. The influence of trees and grass on outdoor thermal comfort in a hot-arid environment. Int J Climatol 2011;31:1498-506. doi: 10.1002/joc.2177

$9 \mathrm{Ng}$ E. Policies and technical guidelines for urban planning of high-density cities - air ventilation assessment (AVA) of Hong Kong. Build Environ 2009;44:1478-88. doi: 10.1016/j.buildenv.2008.06.013 pmid: 32288005

10 Yang J, Wang Z, Kaloush K. Environmental impacts of reflective materials: Is high albedo a 'silver bullet' for mitigating urban heat island?Renew Sustain Energy Rev 2015;47:830-43doi: 10.1016/j.rser.2015.03.092

11 Miao Q, Welch EW, Sriraj PS. Extreme weather, public transport ridership and moderating effect of bus stop shelters. J Transp Geogr 2019;74:125-33. doi: 10.1016/j.jtrangeo.2018.11.007

12 Al-Fouzan SA. Using car parking requirements to promote sustainable transport development in the Kingdom of Saudi Arabia. Cities 2012;29:201-11doi: 10.1016/j.cities.2011.08.009

13 Muneerudeen A, Al Khani F, Furlan R. Urban revitalization of public spaces in the Pearl in Qatar. Am J Sociol Res 2016;6:1-9.

14 Givoni B. Effectiveness of mass and night ventilation in lowering the indoor daytime temperatures. Part I: 1993 experimental periods. Energy Build 1998;28:25-32doi: 10.1016/S0378-7788(97)00056-X

15 Baniassadi A, Heusinger J, Sailor DJ. Energy efficiency vs resiliency to extreme heat and power outages: The role of evolving building energy codes. Build Environ 2018;139:86-94 doi: 10.1016/j.buildenv.2018.05.024

16 Schweitzer O, Erell E. Evaluation of the energy performance and irrigation requirements of extensive green roofs in a water-scarce Mediterranean climate. Energy Build 2014;68:25-32doi: 10.1016/j.enbuild.2013.09.012
17 Konopacki S, Gartland L, Akbari H, Rainer L. Demonstration of energy savings of cool roofs. United States. https://www.osti.gov/biblio/296885-demonstration-energy-savings-cool-roofs

18 Givoni B. Man, climate and architecture. 2nd ed. Applied Science Publishers, 1976: 483

19 Rezaei SD, Shannigrahi S, Ramakrishna S. A review of conventional, advanced, and smart glazing technologies and materials for improving indoor environment. Sol Energy Mater Sol Cells 2017;159:26-51. doi: 10.1016/.j.solmat.2016.08.026

20 Macintyre HL, Heaviside C, Taylor J, etal. Assessing urban population vulnerability and environmental risks across an urban area during heatwaves-Implications for health protection Sci Total Environ 2018;610-611:678-90. doi: 10.1016/j.scitotenv.2017.08.062 pmid: 28822935

21 Loughnan ME, Nicholls N, Tapper NJ. When the heat is on: threshold temperatures for AMI admissions to hospital in Melbourne Australia. Appl Geogr 2010;30:63-9. doi: 10.1016/j.apgeog.2009.08.003

22 Lazzarini M, Molini A, Marpu PR, etal. Urban climate modifications in hot desert cities: The role of land cover, local climate, and seasonality. Geophys Res Lett 2015;42:9980-9. doi: 10.1002/2015GL066534

23 Hochman A, Harpaz T, Saaroni H, etal. The seasons' length in 21st century CMIP5 projections over the eastern Mediterranean. Int J Climatol 2018;38:2627-37. doi: 10.1002/joc.5448

24 Ahmadalipour A, Moradkhani H. Escalating heat-stress mortality risk due to global warming in the Middle East and North Africa (MENA). Environ Int 2018;117:215-25. doi: 10.1016/j.envint.2018.05.014 pmid: 29763817

25 Pal JS, Eltahir EAB. Future temperature in southwest Asia projected to exceed a threshold for human adaptability. Nat Clim Chang 2016;6:197-200. doi: 10.1038/nclimate2833

26 Elfeky S, El-Adawy M, Rashidian A, Mandil A, Al-Mandhari A. Healthy cities programme in the Eastern Mediterranean Region: concurrent progress and future prospects. East Mediterr Health J 2019:25:445-6. doi: 10.26719/2019.25.7.445 pmid: 31612975

27 Ramallah Municipality. Resilient Ramallah 2050. Ramallah: 2018. https://www.ramallah.ps/userfiles/file/ir/Ramallah\%20Resilience\%20Strategy\%202050.pdf.

28 Tel Aviv-Yafo Municipality. The strategic plan for Tel Aviv-Yafo. 2017. https://www.telaviv.gov.il/Residents/Development/DocLib1/City\%20Vision\%202017.pdf

29 Meerow S, Newell JP, Stults M. Defining urban resilience: A review. Landsc Urban Plan 2016;147:38-49. doi: 10.1016/.landurbplan.2015.11.011

30 Erell E, Tsoar H. An experimental evaluation of strategies for reducing airborne dust in desert cities. Build Environ 1997:32:225-36doi: 10.1016/S0360-1323(96)00060-1

31 OECD. OECD policy responses to coronavirus (COVID-19): cities policy responses. 2020. http://www.oecd.org/coronavirus/policy-responses/cities-policy-responses-fd1053ff/

32 Kelly C, Wilson JS, Schootman M, Clennin M, Baker EA, Miller DK. The built environment predicts observed physical activity. Front Public Health 2014;2:52 doi: 10.3389/fpubh.2014.00052 pmid: 24904916

33 Coutts AM, Tapper NJ, Beringer J, etal. Watering our cities. Prog Phys Geogr Earth Environ 2013;37:2-28. doi: 10.1177/0309133312461032

34 Cohen-Shacham E, Janzen C, Maginnis S, etal. Nature-based solutions to address global societal challenges. Gland, 2016doi: 10.2305/IUCN.CH.2016.13.en

35 Livesley SJ, McPherson GM, Calfapietra C. The urban forest and ecosystem services: impacts on urban water, heat, and pollution cycles at the tree, street, and city scale. J Environ Qual 2016:45:119-24. doi: 10.2134/jeq2015.11.0567 pmid: 26828167

36 Schinasi LH, Benmarhnia T, De Roos AJ. Modification of the association between high ambient temperature and health by urban microclimate indicators: A systematic review and meta-analysis Environ Res 2018;161:168-80. doi: 10.1016/j.envres.2017.11.004 pmid: 29149680

37 Wong THF, Brown RR. The water sensitive city: principles for practice. Water Sci Technol 2009;60:673-82. doi: 10.2166/wst.2009.436 pmid: 19657162

38 Ferguson BC, Frantzeskaki N, Brown RR. A strategic program for transitioning to a water sensitive city. Landsc Urban Plan 2013;117:32-45doi: 10.1016/j.landurbplan.2013.04.016

39 Wong THF, Brown RR. The water sensitive city: principles for practice. Water Sci Technol 2009;60:673-82. doi: 10.2166/wst.2009.436 pmid: 19657162

40 Water Services Association of Australia (WSAA). Health benefits from water centric liveable communities. 2019. https://www.wsaa.asn.au/publication/health-benefits-water-centric-liveablecommunities

41 Nieuwenhuiisen MJ, Khreis H, Triguero-Mas M, Gascon M, Dadvand P. Fifty shades of green: pathway to healthy urban living. Epidemiology 2017;28:63-71. doi: 10.1097/EDE.0000000000000549 pmid: 27525811

42 Ferguson BC, Brown RR, Frantzeskaki N, de Haan FJ, Deletic A. The enabling institutional context for integrated water management: lessons from Melbourne. Water Res 2013;47:7300-14. doi: 10.1016/j.watres.2013.09.045 pmid: 24148920

43 Mahmoud AHA. Analysis of the microclimatic and human comfort conditions in an urban park in hot and arid regions. Build Environ 2011;46:2641-56. doi: 10.1016/j.buildenv.2011.06.025

44 Ahmed N, El Aziz A. Pocket park design in informal settlements in Cairo city. Egypt Landsc Archit Reg Plan 2017;2:51-60. doi: 10.11648/j.larp.20170202.12

45 ARUP. Cities alive: rethinking cities in arid environments. ARUP,

2018.https://www.arup.com/perspectives/publications/research/section/cities-alive-cities-in-aridenvironments

46 Fiala D, Havenith G, Bröde P, Kampmann B, Jendritzky G. UTCI-Fiala multi-node model of human heat transfer and temperature regulation. Int J Biometeorol 2012;56:429-41. doi: 10.1007/s00484-011-0424-7 pmid: 21503622 
47 Chokhachian A, Santucci D, Auer T. A human-centered approach to enhance urban resilience, implications and application to improve outdoor comfort in dense urban spaces. Buildings 2017;7:113doi: 10.3390/buildings7040113

48 Erell E, Boneh D, Bar (Kutiel) P, Pearlmutter D. Effect of high-albedo materials on pedestrian thermal stress in urban street canyons. Urban Climate 2014;10:367-86doi: 10.1016/j.uclim.2013.10.005

49 Xiang F, Lucas R, Hales S, Neale R. Incidence of nonmelanoma skin cancer in relation to ambient UV radiation in white populations, 1978-2012: empirical relationships. JAMA Dermatol 2014;150:1063-71. doi: 10.1001/jamadermatol.2014.762 pmid: 25103031

50 Khreis H, Glazener A, Ramani T, et al. Transportation and health: a conceptual model and literature review. 2019. https://www.carteeh.org/14-pathways-to-health-project-brief/

51 Gouldson A, Sudmant A, Khreis H, et al. The economic and social benefits of low-carbon cities: a systematic review of the evidence. 2018. https://newclimateeconomy.report/workingpapers/wpcontent/uploads/sites/5/2018/06/The-Economic-and-Social-Benefits-of-Low-Carbon-Cities-Asystematic-review-of-the-evidence.pdf

52 Böcker L, Dijst M, Faber J. Weather, transport mode choices and emotional travel experiences. Transp Res Part A Policy Pract 2016;94:360-73. doi: 10.1016/j.tra.2016.09.021

53 Shaaban K, Muley D, Elnashar D. Evaluating the effect of seasonal variations on walking behaviou in a hot weather country using logistic regression. Int J Urban Sci 2018;22:382-91. doi: 10.1080/12265934.2017.1403363

54 Wei M, Liu Y, Sigler T, etal. The influence of weather conditions on adult transit ridership in the sub-tropics. Transp Res Part A Policy Pract 2019;125:106-18doi: 10.1016/j.tra.2019.05.003

55 Abubakar IR, Dano UL. Sustainable urban planning strategies for mitigating climate change in Saudi Arabia. Environ Dev Sustain 2020;22:5129-52doi: 10.1007/s10668-019-00417-1

56 Klepeis NE, Nelson WC, Ott WR, et al. The national human activity pattern survey. Lawrence Berkeley NatI Lab2001;11:231-52. http://exposurescience.org/the-national-human-activity-patternsurvey-nhaps-a-resource-for-assessing-exposure-to-environmental-pollutants

57 Boubekri M, Lee J, MacNaughton P, etal. The impact of optimized daylight and views on the sleep duration and cognitive performance of office workers. Int J Environ Res Public Health 2020;17:3219. doi: 10.3390/ijerph17093219 pmid: 32384634

58 Allen JG, MacNaughton P, Satish U, Santanam S, Vallarino J, Spengler JD. Associations of cognitive function scores with carbon dioxide, ventilation, and volatile organic compound exposures in office workers: A controlled exposure study of green and conventional office environments. Environ Health Perspect 2016;124:805-12. doi: 10.1289/ehp.1510037 pmid: 26502459

59 Mendell MJ, Heath GA. Do indoor pollutants and thermal conditions in schools influence student performance? A critical review of the literature. Indoor Air 2005;15:27-52. doi: 10.1111/j.1600-0668.2004.00320.x pmid: 15660567

60 Foruzanmehr A, Vellinga M. Vernacular architecture: questions of comfort and practicability. Build Res Inform 2011;39:274-85. doi: 10.1080/09613218.2011.562368

61 González-Eguino M. Energy poverty: an overview. Renew Sustain Energy Rev 2015:47:377-85. doi: 10.1016/j.rser.2015.03.013

62 Brown RR, Zevenbergen C, Ashley R, Farrelly M, Morison P, van Herk S. Fit-for-purpose governance: A framework to make adaptive governance operational. Environ Sci Policy 2012;22:73-84doi: 10.1016/j.envsci.2012.06.010

This is an Open Access article distributed in accordance with the Creative Commons Attribution Non Commercial (CC BY-NC 4.0) license, which permits others to distribute, remix, adapt, build upon this work non-commercially, and license their derivative works on different terms, provided the original work is properly cited and the use is non-commercial. See: http://creativecommons.org/licenses/bync/4.0/. 